\title{
Kenyan Traditional Medicine: Exploring Old Solutions to the Modern Antibacterial Crises Through Natural Products Chemistry
}

Fidensio K. Ndegwa ${ }^{\mathrm{a}}$, Chaitanya Kondam ${ }^{\mathrm{b}}$, Debarati Ghose ${ }^{\mathrm{c}}$, Taiwo E. Esan ${ }^{\mathrm{b}}$, Zohra Sattar Waxali $^{\mathrm{b}}$, Margaret E. Miller ${ }^{\mathrm{b}}$, Rangaswamy Meganathan ${ }^{\mathrm{c}}$, Nicholas K. Gikonyo ${ }^{\mathrm{a}}$, Paul K. Mbugua ${ }^{\mathrm{d}}$, Paul O. Okemo ${ }^{\mathrm{e}}$, Timothy J. Hagen ${ }^{\mathrm{b}} *$

a Department of Pharmacognosy, Pharmaceutical Chemistry and Pharmaceutical \& Industrial Pharmacy, Kenyatta University, Nairobi, Kenya.

${ }^{b}$ Department of Chemistry and Biochemistry, Northern Illinois University, DeKalb, IL, USA.

${ }^{c}$ Department of Biological Sciences, Northern Illinois University, DeKalb, IL, USA.

${ }^{d}$ Department of Plant sciences, Kenyatta University, Nairobi, Kenya.

${ }^{e}$ Department of Microbiology, Kenyatta University, Nairobi, Kenya.

*corresponding author Timothy J. Hagen, Ph.D., Department of Chemistry and Biochemistry Northern Illinois University, 1425 W. Lincoln Hwy., DeKalb, IL USA 60115 thagen@niu.edu

\section{Abstract:}

Infectious diseases are a major cause of morbidity and mortality around the world, accounting for approximately $50 \%$ of all deaths in tropical countries. Despite remarkable progress in the field of microbiology, inability to control or mitigate, epidemics caused by drug-resistant microorganisms pose a serious health hazard to the global population. New therapeutic strategies must be developed as a global initiative for the prevention and control of infectious diseases. This study focuses on Kenyan medicinal plants and their activity against bacteria. Plant extracts obtained from seven Kenyan plants used in traditional medicine, were screened for their antibacterial activity against Escherichia coli, 
Pseudomonas aeruginosa, Bacillus cereus, and Mycobacterium smegmatis. Extracts from all these plants showed antibacterial activity against at least one of the tested organisms at a concentration of $2 \mathrm{mg} / \mathrm{mL}$. Chemical screening showed the presence of different classes of phytochemicals such as alkaloids, terpenes, tannins, in some active extracts.

Keywords: Kenyan traditional medicine; antibacterial; infectious disease; extracts.

\section{Introduction:}

The World Health Organization (WHO) reported infectious diseases are the major cause of illness and mortality around the world. (Manandhar et al., 2019) WHO estimated that about $50 \%$ of deaths in tropical countries are due to infectious diseases caused by bacteria (Mahady et al., 2005). The rate of mortality caused by multiple drug resistant (MDR), extensively drug resistant (XDR) and pan-drug resistant (PDR) microbes are increasing even in developed countries, such as the United States. Despite the remarkable progress in the field of microbiology, inability to control or mitigate, epidemics caused by drug-resistant microbes pose a serious public health hazard. The Centers for Disease Control (CDC) recommends various approaches for the control of infectious diseases such as vaccination, enhanced monitoring, diagnosis, and development of new therapeutics for the treatment of diseases. New therapeutic strategies must be developed as a global initiative for the prevention and control of infectious diseases (Manandhar et al., 2019).

For centuries, plants have been used for the treatment of various diseases and they can be investigated for the discovery of new antimicrobial agents. Many of the medicinal plant species are active against a wide range of microbes. In many developing countries such as Kenya, the use of medicinal plants for the treatment of various ailments is quite common. It is estimated that about $70 \%$ of the Kenyan population uses medicinal plants for primary health care. Divergent Kenyan communities like Ogiek, Taita, and Maasai use medicinal 
plants as therapeutics since they live far away from modern medical facilities. In the Ogiek community, $96 \%$ of the population uses medicinal plants as their major therapeutic agents (Ndegwa, 2008). Various studies have reported the antimicrobial properties and efficacy of Kenyan medicinal plants (Nankaya et al., 2019). Evaluation of the medicinal properties of such plants can lead to the discovery and isolation of new therapeutic agents for the treatment of infectious diseases.

In this study, seven different Kenyan medicinal plants, A. апnиa, A. remota, $P$. peruviana, $P$. africana, C. africana, S. didymobotrya, and B. micrantha were chosen because these plants are commonly used for the treatment of malaria, pneumonia, diarrhea, and other diseases. Extracts were made from various plant parts using water, methanol, acetone, and hexane solvents and screened against four different strains of bacteria; E. coli, P. aeruginosa, B. cereus and M. smegmatis using the Kirby-Bauer disc diffusion assay (Goshu et al., 2015).

\section{Materials and Methods}

The botanical information on the traditional medicinal plants of Kenya, used in this study are presented in Table1. Each plant sample was extracted with at least one or more of the following solvents: water, methanol, acetone and hexane. Depending on the availability, the samples were tested for antibacterial activity and the results are presented in Table 2. The antimicrobial compounds, kanamycin, nalidixic acid, and neem oil (Azadirachta indica) were used as positive controls. The phytochemical analysis and methods used in the preparation of plant extract samples are described in the supplemental material section.

Table 1: Medicinal plants tested for their antibacterial activity in the study

\section{Results and discussion}


It was observed that extracts of Artemisia annua, Ajuga remota, Physalis peruviana, Prunus africanus, Cordia africana, Senna didymobotrya, and Bridelia micrantha significantly inhibited growth of various bacteria as determined by Kirby Bauer disc diffusion method (Table 2).

A. аппиа extracts prepared with water were effective against all four organisms at 2.0 $\mathrm{mg} / \mathrm{ml}$. The acetone extract was twice as effective as the water extract against $P$. aeruginosa and B. cereus. B. cereus was very sensitive to acetone extract since it was inhibited even at $0.2 \mathrm{mg} / \mathrm{ml}$. The hexane extract was ineffective against $P$. aruginosa.

Extracts of $B$. micrantha prepared with water, methanol and hexane were highly effective against all the four organisms. B. cereus was highly sensitive to methanol extract since it was inhibited even by the low concentration of $0.2 \mathrm{mg} / \mathrm{ml}$. Surprisingly, E. coli was resistant to acetone extract in contrast to the other three organisms.

The $C$. africana extracts in water or methanol were active against $P$. aruginosa, B. cereus and $M$. smegmatis while $E$. coli was resistant. In contrast, the hexane extract was active against all organisms except $P$. aruginosa. B. cereus was very sensitive to the hexane extract since it was effective even at the low concentration of $0.2 \mathrm{mg} / \mathrm{ml}$. The pattern of inhibition exhibited by the water extract of $P$. peruviana is similar to that of $C$. Africana methanol extract in that they both inhibited P. aruginosa, B. cereus and M. smegmatis.

Surprisingly, depending on the solvent used $P$. africanus extracts showed wide variation in their effect on the bacteria tested. The water extract inhibited only the two Gram positive B. cereus and M. smegmatis. P. aruginosa, E. coli and B. cereus were found to be sensitive to acetone extract in contrast to $M$. smegmatis which was resistant. The sensitivity of Gramnegative $P$. aruginosa and Gram-positive $M$. smegmatis for the hexane extract was about the same as shown by the diameter of the zone of inhibition. 
The water extract of S. didymobotrya inhibited all the four organisms. In contrast, the hexane and methanol extracts were effective against the two Gram-positive bacteria tested. The methanol extract was very effective against B. cereus since it was inhibitory even at the low concentration of $0.2 \mathrm{mg} / \mathrm{ml}$.

\section{Table 2: Determination of anti-bacterial activity}

Phytochemicals are vital components of plants that are responsible for antifungal and antibacterial properties. A. аппиа extract showed anti-bacterial and anti-fungal activity (Rolta et al., 2021). Phytochemical screening showed the presence of tannins, steroids, carbohydrates, proteins/amino acids, flavonoids, anthraquinones, and terpenoids. A. аппиа plant extract also has antioxidant activity due to the presence of tannins (Bora et al., 2011).

Preliminary phytochemical screening of A. remota extracts showed the presence of tannins, flavonoids, steroids, carbohydrates, proteins, cardiac glycosides, anthraquinones, and terpenoids in the extracts. The extracts of A. remota were reported to show significant antidiabetic effect as these phytochemicals enhance the activity of glycolytic enzymes (Tafesse $e t$ $a l .$, 2017). The extracts were also reported to have antidiarrheal and antimalarial activity (Yacob et al., 2016). The steroidal metabolite ergosterol-5,8 endoperoxide isolated from this plant acts as a potential anti-bacterial agent (Yong, et al., 2014).

B. micrantha extract contains, alkaloids, tannins, anthraquinones, steroids and flavonoids and were reported to exhibit antibacterial activity against various bacteria and reported to exhibit antioxidant and antihaemolytic properties (Adefuye et al., 2013).

Chemical analysis of $C$. africana extracts showed the presence of flavonoids, tannins, steroids, carbohydrates, and cardiac glycosides. The extracts exhibited antibacterial, antiinflammatory and antioxidant activity. Further, it was reported to exhibit antiulcer activity in pyloric ligated rats (Yismaw et al., 2020). 
P. peruviana contains tannins, steroids, anthraquinones, flavonoids, terpenoids by phytochemical analysis and reported to have anti-bacterial and anti-fungal activity. Extracts from various parts of this plant exhibited anti-parasitic effect against the malarial parasite activity against Plasmodium falciparum. (Kamau et al., 2020).

The stem bark of $P$. africanus has been used as a remedy for stomach-ache, as a laxative for cattle, and prostate cancer (Onyancha et al; 2018). Tannins and anthraquinones in the bark extract show antioxidant activity (Mwangi et al., 2018). Phytochemical analysis of the bark showed the presence of carbohydrates, tannins, flavonoids and terpenes. Stem bark extract showed an anti-inflammatory effect in mice and can be used to isolate potent antiinflammatory compounds (Ngeranwa et al., 2020).

Our phytochemical analysis revealed that $S$. didymibotrya contains steroids, alkaloids, tannins, carbohydrates, cardiac glycosides, anthraquinones, terpenoids and flavonoids. The leaf extracts were reported to show analgesic activity in mice models and reported to have anti-bacterial and anti-fungal activity (Jeruto et al., 2017).

\section{Conclusion}

In summary, the results presented in this report provide strong evidence that extracts of $A$. annua, A. remota, P. peruviana, P. africanus, C. africana, S. didymobotrya, and B. micrantha have antibacterial activity against E. coli, P. aeruginosa, B. cereus and M. smegmatis. Of particular significance is the effectiveness of extracts of every plant against $P$. aeruginosa, which is resistant to several antibiotics and an opportunistic pathogen of immunocompromised individuals and chronic lung diseases patients.

A significant finding is the effectiveness of the plant extracts against the Gram-positive pathogen, B. cereus. This bacterium is a spore former and usually causes food poisoning and eye infections. However, it is increasingly reported to cause fatal non-intestinal infections such as fulminant sepsis, central nervous system infections and hospital acquired infections, 
particularly in immunosuppressed patients. Examination of the results in Table 2 reveals that every plant examined, irrespective of the solvent used was inhibitory to B. cereus except for P. africanus hexane extract. Furthermore, four of the plant extracts from different solvents were inhibitory at $0.2 \mathrm{mg} / \mathrm{ml}$. Many of the same plant extracts also inhibited the other Grampositive bacterium $M$. smegmatis except for water extracts of A. annua and A. remota and acetone extract of $P$. africanus.

The very effective inhibitory properties of these plant extracts hold great promise in discovering new antibiotics. From the results in Table 2, it is obvious that these plant extracts were far more effective against the two Gram positive B. cereus and M. smegmatis than the two Gram-negative bacteria. These plant extracts can be used as prospective sources for the development of anti-microbial agents. Further attempts to identify and purify the active components from these extracts will give rise to promising antibacterial lead compounds that may be developed to meet the urgent need for new antibiotics.

\section{Supplemental material}

Experimental details related to this paper is available online

\section{Acknowledgement}

The authors acknowledge Northern Illinois University and Kenyatta University for supporting and funding this work.

\section{Disclosure statement}

No potential conflict of interest was reported by the authors

\section{References}

Adefuye, A. O., \& Ndip, R. N. (2013). Phytochemical analysis and antibacterial evaluation of the ethyl acetate extract of the stem bark of Bridelia micrantha. Pharmacognosy Magazine, 9(33), 45-50. doi: 10.4103/0973-1296.108139

Bora, K. S., \& Sharma, A. (2011). The GenusArtemisia: A comprehensive review. Pharmaceutical Biology, 49(1), 101-109. https://doi.org/10.3109/13880209.2010.497815 
Goshu, G. M., Ghose, D., Bain, J. M., Pierce, P. G., Begley, D. W., Hewitt, S. N., ... Hagen, T. J. (2015). Synthesis and biological evaluation of pyrazolopyrimidines as potential antibacterial agents. Bioorganic \& Medicinal Chemistry Letters, 25(24), 5699-5704. https://doi.org/10.1016/j.bmcl.2015.10.096

Jeruto, P., Arama, P. F., Anyango, B., \& Maroa, G. (2017). Phytochemical screening and antibacterial investigations of crude methanol extracts of Senna didymobotrya (Fresen. $H S$ Irwin \& Barneby. Journal of Applied Biosciences, 114, 11357-11367. DOI: $\underline{10.4314 / j a b . v 114 i 1.9}$

Kamau, P. K., Njeruh, F. M., Kirira, P. G., Kolawole, O. A., Kolawole, O. E., Marbel, O. T., \& Banjo, S. (2020). An Assessment of Antibacterial and Antifungal Activity of Methanolic Extracts of Kenyan Physalis peruviana. International Journal of Traditional and Natural Medicines, 10(1), 1-12.

Manandhar, S., Luitel, S., \& Dahal, R. K. (2019). In vitro antimicrobial activity of some medicinal plants against human pathogenic bacteria. Journal of Tropical Medicine, 2019, 1895340. https://doi.org/10.1155/2019/1895340

Mwangi, K. J., Kariuki, K. J., Reuben, T., \& Kibe, K. G. The phytochemical components and acute toxicity of methanolic stem bark extract of Prunus africana. IOSR Journal of Pharmacy (IOSRPHR), vol. 8, no. 12, 2018, pp. 39-45.

Ngeranwa, J., G'ori, K., A., M., \& Kiruki, S. (2020). Phytochemical and anti-inflammatory analysis of Prunus africana bark extract. Research Journal of Pharmacognosy, 7(4), 3138.

https://dx.doi.org/10.22127/rjp.2020.229941.1583

Ndegwa, F. K. (2008). Use, Conservation and Harvesting of Medicinal Plants by the Ogiek of East Mau Forest, Nakuru District, Kenya. Kenyatta University. http://irlibrary.ku.ac.ke/handle/123456789/1664

Nankaya, J., Gichuki, N., Lukhoba, C., \& Balslev, H. (2019). Medicinal plants of the Maasai of Kenya: A review. Plants, 9(1), 44. https://doi.org/10.3390/plants9010044

Onyancha, J. M., Gikonyo, N. K., Wachira, S. W., Mwitari, P. G., \& Gicheru, M. M. (2018). Anticancer activities and safety evaluation of selected Kenyan plant extracts against breast cancer cell lines. Journal of Pharmacognosy and Phytotherapy, 10(2), 21-26. http://erepository.mku.ac.ke/handle/123456789/5560

Rolta, R., Sharma, A., Sourirajan, A., Mallikarjunan, P. K., \& Dev, K. (2021). Combination between antibacterial and antifungal antibiotics with phytocompounds of Artemisia annua L: A strategy to control drug resistance pathogens. Journal of Ethnopharmacology, 266(113420), 113420. https://doi.org/10.1016/j.jep.2020.113420

Tafesse, T. B., Hymete, A., Mekonnen, Y., \& Tadesse, M. (2017). Antidiabetic activity and phytochemical screening of extracts of the leaves of Ajuga remota Benth on alloxaninduced diabetic mice. BMC Complementary and Alternative Medicine, 17(1), 243. https://doi.org/10.1186/s12906-017-1757-5

Yacob, T., Shibeshi, W., \& Nedi, T. (2016). Antidiarrheal activity of $80 \%$ methanol extract 
of the aerial part of Ajuga remota Benth (Lamiaceae) in mice. BMC Complementary and Alternative Medicine, 16(1), 1-8. https://doi.org/10.1186/s12906-016-1277-8

Yong, J., \& Ntie-Kang, F. (2014). Potential natural antimycobacterial metabolites from some sub-Saharan medicinal plants. Anti-Infective Agents, 12(2), 178-190. DOI: $\underline{10.2174 / 2211352512666140417002335}$

Yismaw, Y. E., Abdelwuhab, M., Ambikar, D. B., Yismaw, A. E., Derebe, D., \& Melkam, W. (2020). Phytochemical and antiulcer activity screening of seed extract of Cordia africana lam (Boraginaceae) in pyloric ligated rats. Clinical Pharmacology: Advances and Applications, 12, 67-73. doi: 10.2147/CPAA.S245672

Table 1: Medicinal plants tested for their antibacterial activity in the study

\begin{tabular}{|c|c|c|c|c|c|}
\hline Family Name & Botanical Name & Common Name & Part Used & Preparation & Traditional use \\
\hline Asteraceae & Artemisia annиа & Sweet wormwood & Leaf, flower & Decoction & $\begin{array}{l}\text { Malaria, } \\
\text { Psoriasis, } \\
\text { Infections }\end{array}$ \\
\hline Lamiaceae & Ajuga remota & Bugleweed & Leaf & Decoction & $\begin{array}{l}\text { Malaria, } \\
\text { Chest pains }\end{array}$ \\
\hline Solanaceae & $\begin{array}{l}\text { Physalis } \\
\text { peruviana }\end{array}$ & Cape gooseberry & Leaf & Decoction & $\begin{array}{l}\text { Typhoid, } \\
\text { Pneumonia }\end{array}$ \\
\hline Rosaceae & Prunus africana & Red stinkwood & $\begin{array}{l}\text { Stem } \\
\text { bark }\end{array}$ & Decoction & $\begin{array}{l}\text { Pneumonia / } \\
\text { chest pain, loss } \\
\text { of appetite }\end{array}$ \\
\hline Boraginaceae & Cordia africana & Giku & Bark, leaf & Decction & $\begin{array}{l}\text { fatigue, anti- } \\
\text { inflammatory }\end{array}$ \\
\hline Fabaceae & $\begin{array}{l}\text { Senna } \\
\text { didimobotrya }\end{array}$ & Candelabra tree & Leaf & $\begin{array}{l}\text { Decoction, } \\
\text { steam }\end{array}$ & Pneumonia \\
\hline Euphorbiacece & $\begin{array}{l}\text { Bridelia } \\
\text { micrantha }\end{array}$ & Mitzeeeri & Stem bark & Chew & Chest pains \\
\hline
\end{tabular}

Kenyan medicinal plants, traditional preparation and use that were utilised in the study. 


\section{Table 2: Determination of antibacterial activity}

Diameter of zones of inhibition (ZOI) was (measured in mm.) for plant extracts against bacteria at $2 \mathrm{mg} / \mathrm{mL}$ and $0.2 \mathrm{mg} / \mathrm{mL}$ concentrations.

\begin{tabular}{|c|c|c|c|c|c|c|c|c|}
\hline \multirow{2}{*}{\begin{tabular}{|l|} 
Extract \\
Dose in $\mathrm{mg} / \mathrm{mL}$ \\
\end{tabular}} & \multicolumn{2}{|c|}{ E. coli } & \multicolumn{2}{|c|}{ P.aeruginosa } & \multicolumn{2}{|c|}{ B. cereus } & \multicolumn{2}{|c|}{ M.smegmatis } \\
\hline & 2 & 0.2 & 2 & 0.2 & 2 & 0.2 & 2 & 0.2 \\
\hline A. annua (water) & 11 & 0 & 11 & 0 & 10 & 0 & 11 & 0 \\
\hline A. апnиа (acetone) & 10.5 & 0 & 19 & 0 & 18.5 & 7.5 & 0 & 0 \\
\hline A. аnnua (hexane) & 8 & 0 & 0 & 0 & 15 & 0 & 12 & 0 \\
\hline A. remota (water) & 0 & 0 & 8 & 0 & 7 & 0 & 0 & 0 \\
\hline B. micrantha (water) & 10 & 0 & 10.5 & 0 & 16 & 0 & 16 & 0 \\
\hline B. micrantha (methanol) & 11 & 0 & 14 & 0 & 17.5 & 7.5 & 11.5 & 0 \\
\hline B. micrantha (acetone) & 0 & 0 & 12 & 0 & 16 & 0 & 15 & 0 \\
\hline B. micrantha (hexane) & 8.5 & 0 & 12.5 & 0 & 15 & 0 & 19 & 0 \\
\hline C. africana (water) & 0 & 0 & 9.5 & 0 & 7.5 & 0 & 9 & 0 \\
\hline C. africana (methanol) & 0 & 0 & 13 & 0 & 10 & 0 & 12 & 0 \\
\hline C. africana (hexane) & 10 & 0 & 0 & 0 & 17.5 & 7 & 9 & 0 \\
\hline P. peruviana (water) & 0 & 0 & 12 & 0 & 7 & 0 & 11.5 & 0 \\
\hline P. africanus (water) & 0 & 0 & 0 & 0 & 17 & 0 & 12.5 & 0 \\
\hline P. africanus (acetone) & 10 & 0 & 10.5 & 0 & 20 & 0 & 0 & 0 \\
\hline P. africanus (hexane) & 0 & 0 & 12.5 & 0 & 0 & 0 & 12 & 0 \\
\hline S. didymobotrya (water) & 8.5 & 0 & 11.5 & 0 & 19.5 & 9 & 11 & 0 \\
\hline S.didymobotrya (methanol) & 0 & 0 & 0 & 0 & 19 & 8.5 & 12 & 0 \\
\hline S. didymobotrya (hexane) & 0 & 0 & 0 & 0 & 11 & 0 & 11 & 0 \\
\hline Kanamycin (control) & 23 & 13 & 0 & 0 & 27 & 20 & 27 & 18 \\
\hline Nalidixic acid (control) & 10 & 0 & 10 & 0 & 33 & 25 & 9 & 0 \\
\hline $\begin{array}{l}\text { Azadirachta indica } \\
\text { (Neem oil) (control) }\end{array}$ & 13 & 0 & 12 & 0 & 10 & 0 & 12 & 0 \\
\hline
\end{tabular}

